\title{
ROMAN HRVOJA KOVAČEVIĆA TAJNA MAČJE ŠAPE KAO PARADIGMATSKI PRIMJER LINGVODIDAKTIČKOGA PREDLOŠKA U NASTAVI HRVATSKOGA JEZIKA
}

\section{Sažetak}

Lingvodidaktički predložak u stručnoj se literaturi definira kao funkcionalni izvorni tekst analizom kojega se postižu kognitivni ciljevi i usvajaju jezični sadržaji. Roman Hrvoja Kovačevića Tajna mačje šape lektirni je naslov u 4. razredu osnovne škole te je predviđen za analizu u okviru nastave književnosti. No, budući da je riječ o izrazito slojevitome tekstu, vrlo svrhovito može poslužiti i kao paradigmatski primjer lingvodidaktičkoga predloška u procesu učenja i poučavanja materinskoga jezika.

S književno-umjetničkoga aspekta, Kovačevićev je roman zanimljiv i vrlo dinamičan umjetnički tekst, razgranate fabule i jasne strukture, socijalno osjetljiv i s dozom simbolike koja usmjerava mlade čitatelje na prave životne vrijednosti. S lingvostilističkoga aspekta, što je tematika ovoga rada, riječ je o tekstu zasićenome kratkim, razumljivim i logičnim rečenicama primjerene sintakse i stila, sadržajno cjelovitim i dovoljno obavijesnim dijalozima primjerenima svakodnevnome izražavanju te bogatim rječnikom koji obilježava povremeni odmak u zavičajnu ili dobnu komunikaciju.

Stoga će u radu, sukladno načelu korelacije i integracije nastavnih sadržaja unutar jezično-komunikacijskoga i jezično-umjetničkoga područja, pojedini ulomci Kovačevićeva romana poslužiti kao poticajno polazište za stvaralačku, zanimljivu i svrhovitu nastavu hrvatskoga jezika.

Ključne riječi: lingvodidaktički predložak; nastava hrvatskoga jezika u osnovnoj školi; dječja književnost; romani Hrvoja Kovačevića. 


\section{UVOD}

\section{Zašto baš Hrvoje Kovačević?}

Hrvoje Kovačević jedan je od najproduktivnijih suvremenih hrvatskih književnika. Od objave prvoga romana (Tajna ribljega oka, 1996.) napisao je i publicirao više od trideset naslova. Iako se taj rođeni Požežanin, inače diplomirani arhitekt, pisanjem dječjih priča počinje baviti još početkom 90-ih godina prošloga stoljeća, profesionalni je pisac od 2001. godine. Dobitnik je prestižne nagrade Grigor Vitez za roman Tajna crne kutije (1998.), a za dramu Profesionalna deformacija nagrađen je nagradom Sfera (2008.). Kovačević je ujedno jedan od najčitanijih dječjih pisaca te najsvestranijih hrvatskih književnika. Piše za djecu i odrasle, piše romane, priče, slikovnice, dramske tekstove, scenarije, novinske članke. Uz to, autor je jednoga igranoga i triju animiranih filmova, bavio se ilustriranjem slikovnica i crtanjem karikatura za razne časopise kao što su Studentski list, Polet i Sportske novosti. Kratke priče i drame objavljene su mu u zbirkama i časopisima ili su izvedene na radiju.

Iako je Kovačević vrlo uspješno pisao i prozu za odrasle, šira ga čitateljska publika ponajprije prepoznaje kao autora brojnih dječjih romana, ponajprije po seriji tzv. mystery romana koji u naslovu imaju riječ tajna (Tajna ribljeg oka, Tajna crne kutije, Tajna Zmajeva vrta, Tajna Zlatnog zuba, Tajna mačje šape, Tajna tužnog psa, Tajna graditelja straha, Tajna šutljivog dječaka, Tajna sretnih susjeda, Tajna šaptača lubenicama, Tajna Titana Horvata, Tajna Stubičkih Toplica, Tajna Zantara Vidovnjaka). Inspiraciju za živopisne likove u dječjim pričama i romanima, kako sâm ističe, dobiva iz mašte svoje djece.

\section{Zašto baš roman Tajna mačje šape?}

Roman Tajna mačje šape objavljen je 2002. godine. Budući da je prva naklada brzo rasprodana, 2006. godine tiskano je novo izdanje, što pokazuje da je riječ o jednome od čitanijih djela ne samo u opusu Hrvoja Kovačevića nego i općenito među romanima za djecu. Djelo je ubrzo uvršteno u popis lektirnih naslova za 4. razred osnovne škole i sustavno se obrađuje u okviru nastave književnosti. Budući da je roman objavljen u biblioteci Moja knjiga - metodički obrađena lektira (Školska knjiga, 2013.), popraćen je poticajima za vođenje dnevnika čitanja te metodičkim uputama za što uspješniju provedbu književnoteorijske analize tijekom koje valja obratiti pozornost na niz čimbenika, npr. razmišljanje o pročitanome djelu, promišljanje o temi, izražavanje doživljaja i zaključaka, uočavanje posebnosti vremena, prostora i radnje, analizu likova, objašnjenja nepoznatih riječi...). Na taj način učenici mogu dobro upoznati djelo, pa je veća vjerojatnost da lingvostilistička analiza, koja se provodi nakon književnoteorijske, bude funkcionalna i svrhovita. 
Osim toga, roman Tajna mačje šape vrlo je slojevito i po mnogim obilježjima drukčije djelo u odnosu na ostale "tajne“. U njemu se iščitava poseban binaran odnos na nekoliko razina. Dvojnost je uočljiva ponajprije na tematskoj razini jer je tema romana istodobno i avanturistička i realistična, a zatim i na sadržajnoj razini jer se ujedno realiziraju futuristički elementi (znanstvena fantastika) i svakodnevne životne situacije (mjesto i vrijeme radnje). Dvojnost pronalazimo i u prezentaciji likova koji su na prvi pogled uobičajeni, ali i unikatni te pomalo drukčiji u odnosu na društvenu sredinu.

\section{Književnoznanstveni i/ili jezikoslovni pristupi umjetničkome tekstu - teorijski okvir}

U najširem smislu, pojam teksta (lat. textus = tkanje, tkivo, sveza riječi) označava izgovoren ili napisan slijed misli oblikovan u riječi i rečenice (Rječnik hrvatskoga jezika, 2000.), odnosno svaku smislenu jezičnu (sintaktičku) cjelinu veću od rečenice (Samardžija, M. i Selak, A., 2001.; 696) koja je ustrojena prema pravilima nekoga jezika.

Znanost o književnosti koja razmatra svekolika svojstva književnoga izričaja i sve različite odnose unutar kojih se umjetnička djelatnost ostvaruje tekstom općenito smatra stvaralačku autorsku tvorevinu u pisanome (tiskanome) obliku koja ima posebna obilježja, npr. figurativnost, pripadnost književnoj vrsti i funkcionalnome stilu, prepoznatljivu jezičnu građu, specifične kreativne i umjetničke odrednice. Zahvaljujući upravo tim odlikama, tekst se u nastavi književnosti povezuje s književnom analizom te s proučavanjem književnoteorijskih i stilističkih obilježja teksta kao umjetničkoga djela.

U jezikoslovnoj znanosti, pak, tekst razumijeva niz manjih jezičnih jedinica koje se prema određenim pravilima ustrojavaju u veću dovršenu cjelinu (Silić, J. i Pranjković, I., 2005: 359). U Hrvatskoj gramatici (Barić i sur. 1995: 392) pojam teksta povezuje se s pojmom diskursa kao koherentne jezične cjeline u kojoj je „egzaktno utvrdiva ovisnost jednih jezičnih jedinica o izboru drugih". U okviru znanosti o tekstu, tekstna lingvistika određuje tekst kao polaznu jedinicu, odnosno sintaktičku cjelinu organiziranu po zakonima gramatike, semantike i logike određenoga jezika. Sintaksa teksta ili diskursa proučava jezično ustrojstvo najviše razine, tj. sintaktičke odnose u diskursu većemu od rečenice, a to je tekst. Riječ je, dakle, o nadrečeničnoj cjelini koja predstavlja razumljiv, organiziran i dovršen slijed riječi opsežniji od rečenice s temeljnom priopćajnom svrhom. Obilježja tako shvaćena pojma teksta jesu povezanost i smislenost jezičnih jedinica, informativnost te ostvaraj komunikacije. Pritom svaki tekst, u pisanome ili izgovorenome obliku, kraći ili duži, prozni ili poetski, književni ili neknjiževni, racionalnoga ili emocionalnoga stila izražavanja, 
karakteriziraju sljedeće odrednice: povezanost gramatičkih (ponajprije sintaktičkih) jedinica, smislenost i obavijesnost leksičkih jedinica te pragmatički ostvaraj komunikacijske funkcije.

Budući da je jezik izražajno sredstvo književnosti kao „umjetnosti riječi“, većina teoretičara književnosti, kao i jezikoslovaca, ističe poveznicu između književnosti i jezika. Milivoj Solar (2005.) naglašava da je književno djelo tekst koji valja ponajprije shvatiti kao bilo koji tekst, a smisao književnog djela dobiva se tek ako uzmemo u obzir i kontekst. I u teoriji Ferdinanda de Saussurea možemo pronaći poveznicu između književnoga djela i jezika. On u jezikoslovlje uvodi pojam jezičnoga znaka (2000.) kao osnovnu semiotičku jedinicu. Tako shvaćen, znak je ustvari proizvod ljudske djelatnosti koji „preslikava“ neki podatak ili pojavu, a da s njima nužno ne mora imati prirodnu svezu. Budući da su i književna djela znakovi osobite vrste, u tom se smislu može govoriti o semiotici književnosti nastaloj u okviru strukturalizma.

U nastavi jezika proučavanje teksta, posebice ako je riječ o književnome tekstu koji služi kao lingvodidaktički predložak, mora biti u skladu ne samo s umjetničkim i jezikoslovnim kriterijima nego valja imati na umu i opća didaktička načela. Ponajprije načelo primjerenosti, zanimljivosti i stvaralaštva. Takvi tekstovi moraju korespondirati s učenikovim interesima, psihokognitivnim mogućnostima i razvojnom dobi (Howe, 2002.). Iako lingvodidaktički predložak može biti bilo koji funkcionalni tekst, prednost je odabira književnih tekstova upravo njihova umjetnička vrijednost i sadržajna poticajnost te mogućnost korelacije nastave jezika i književnosti. Osim toga, većina književnih tekstova namijenjenih djeci, uključuje pedagoške čimbenike i izražene odgojne sadržaje. Odaberemo li za jezikoslovnu analizu samo ulomak teksta, a ne cijeli tekst, taj dio mora biti zaokružena cjelina, odnosno ulomak mora biti dovoljno obavijestan u sadržajnom smislu kako bi ga se moglo razumjeti i izvan književnog djela.

Tematizirajući tekst s lingvometodičkoga stajališta Stjepko Težak u knjizi Teorija i praksa nastave hrvatskoga jezika (1996: 100) definira tekst kao „izvor i uvir nastave hrvatskoga jezika, što znači da ta nastava polazi od teksta i tekstu se vraća, jer joj je stvaranje uspješnih govorenih i pisanih tekstova napokon i svrha." Jedno od načela koje se u nastavi hrvatskog jezika i u oblikovanju motivacijskih postupaka obvezno uzima u obzir jest načelo sadržajne, tekstovne i stilske raznovrsnosti. Učenik mora upoznati hrvatski jezik na raznovrsnim sadržajima, tekstovima i funkcionalnim stilovima. Unatoč širokom rasponu sadržaja koji nude književna djela, nastavnici moraju znati izabrati tekstove s raznolikim, ali učeniku bliskim i potrebnim sadržajima te ih upoznati s različitim stilovima. Budući da učenicima mlađe školske dobi usvajanje gramatičko-pravopisnih sadržaja, zbog apstraktnosti jezikoslovnoga sadržaja, većinom predstavlja poteškoću, nastavu gramatike trebalo bi učiniti što zanimljivijom i privlačnijom, koliko god to dopušta narav gradiva. Jedan od uspješnijih 
načina svakako jest povezivanje nastave jezika s nastavom književnosti, a kao ishodište za obradu ili utvrđivanje jezikoslovnoga znanja može poslužiti lingvodidaktički predložak. Najbrojniji je motivacijski postupak upravo motivacija tekstom.

Lingvodidaktički se predložak u stručnoj literaturi definira kao funkcionalan izvorni tekst, tekst-uzorak ili ishodišni tekst (Težak, 1998.; Rosandić, 2002.), analizom kojega se postižu kognitivni ciljevi i usvajaju jezični sadržaji. Tekst predloška može biti književni ili neknjiževni, cjelovit ili samo ulomak (ali dovoljno sadržajno jasan kako bi se mogao razumjeti i izvan književnog djela kao zaokružene cjeline), prikladnoga rječnika i sintakse te u skladu s temeljnim didaktičkim načelima, ponajprije s načelom primjerenosti, zanimljivosti, životnosti i stvaralaštva. Predložak se može koristiti u svim etapama nastavnoga sata: u uvodnome dijelu za motiviranje učenika, u dijelu koji se odnosi na obradu novoga gradiva, u završnome dijelu sata tijekom kojega se utvrđuje i vježba jezično gradivo. Pritom je važno osmisliti primjerene i funkcionalne načine kojima će se smanjiti apstraktnost gramatičkih sadržaja te učenicima na što smisleniji i zanimljiviji način približiti jezikoslovni sadržaj. U radu s ishodišnim tekstom - predloškom, valja istaknuti i načelo stvaralaštva. Nastava hrvatskog jezika mora biti stvaralačka, kako za učenika tako i za nastavnika, a rad na zanimljivu i primjerenu tekstu upravo otvara niz mogućnosti za stvaralačke pristupe u procesu usvajanja hrvatskoga standardnoga jezika. Jezik je neiscrpan izvor za stvaranje, a nastava koja potiče stvaralaštvo kod učenika istodobno pridonosi razvoju kreativnosti.

Stoga će u radu, sukladno načelu korelacije i integracije nastavnih sadržaja unutar jezično-komunikacijskoga i jezično-umjetničkoga područja, pojedini ulomci romana Hrvoja Kovačevića Tajna mačje šape poslužiti kao poticajno polazište za stvaralačku, zanimljivu i svrhovitu nastavu hrvatskoga jezika.

\section{Roman Tajna mačje šape kao paradigmatski primjer lingvodidaktičkoga predloška}

Kovačevićev roman Tajna mačje šape, kako je već istaknuto, lektirni je naslov u 4. razredu osnovne škole te je predviđen za analizu u okviru nastave književnosti. No, budući da je riječ o izrazito slojevitome tekstu, odabrani ulomci mogu se vrlo svrhovito iskoristiti kao ishodišni tekstovi, odnosno funkcionalni lingvodidaktički predlošci u nastavi jezika.

Roman se dakle u procesu učenja i poučavanja materinskoga jezika može tretirati dvojako. Ponajprije s umjetničkoga aspekta, kada se tekst proučava tijekom književnoteorijske raščlambe, ali i s jezikoslovnoga aspekta, kada proučavanje teksta uključuje jezikoslovnu, odnosno lingvodidaktičku i lingvostilističku analizu. Upravo taj potonji aspekt tema je ovoga rada. 
S književnoteorijskoga stajališta roman je zanimljiv i vrlo dinamičan umjetnički tekst, razgranate fabule i jasne strukture, socijalno osjetljiv i s dozom simbolike koja usmjerava mlade čitatelje na prave životne vrijednosti. Priča govori o ljubavi i prijateljstvu, o zajedništvu koje u konačnici rezultira ostvarenjem plemenita cilja, bez obzira na moguće prepreke. U djelu se jasno iščitava pouka o tome da stvari često nisu onakvima kakvima se na prvi pogled čine, pa ljude ne bismo trebali osuđivati prije nego li ih doista upoznamo.

S jezikoslovnoga aspekta, roman Tajna mačje šape poslužio je kao paradigmatski primjer lingvodidaktičkoga predloška. Riječ je o tekstu zasićenome kratkim, razumljivim i logičnim rečenicama primjerene sintakse i stila, što ga čini prikladnim za usvajanje gramatičkih i stilističkih obilježja hrvatskoga jezika. Roman karakterizira bogat i raznolik rječnik u kojemu se očituje povremeni odmak u zavičajnu ili dobnu komunikaciju, što se može iskoristiti tijekom provođenja leksičkih govornih vježbi te pri upoznavanju dijalektalnih obilježja hrvatskoga jezika. Također, djelo je prepuno sadržajno cjelovitih i dovoljno obavijesnih dijaloga iz svakodnevne komunikacije, pa je primjereno za nastavu jezičnoga izražavanja. Gotovo sve stilsko-kompozicijske vježbe mogu se usvajati na temelju ulomaka iz Kovačevićeva romana. Od monoloških, dijaloških do poliloških formi, kao što su npr. opisivanje, pripovijedanje, prepričavanje, raspravljanje, razgovorne igre, rekreativni razgovor, usmena dramatizacija... Osim toga, pisana je razina teksta u suglasju s govorenim jezikom, pa djelo obiluje ranolikim interpunkcijskim znakovima, što je pogodno za usvajanje pravopisnih obilježja hrvatskoga jezika te s njima povezanih vrednota govorenoga jezika (npr. intonacija, intenzitet, tempo, stanke...). Jezikoslovni aspekt proučavanja teksta nužno zahtijeva poznavanje, osim sintakse, još nekih jezičnih disciplina, ponajprije semantike i stilistike. Semantika (grč. semantikos, koji daje znakove, značajan, od sema= znak) znanost je o jezičnim značenjima. Proučava jezični sadržaj na svim razinama - od morfema, riječi, sintagme, rečenice do teksta. Stilistika (grč. stylos = rezaljka, pisaljka, štapić za oblikovanje), kao znanost o stilovima izražavanja, bavi se proučavanjem načina oblikovanja izričaja u govorenome i pisanome tekstu. No, tema rada nije književnoznanstvena stilistika nego lingvistička stilistika na svim svojim razinama: grafostilističkoj, fonostilističkoj, morfostilističkoj, sintaktostilističkoj, leksikostilističkoj, semantostilističkoj.

Sukladno svemu navedenome, vidljivo je da Kovačićev roman „Tajna mačje šape" ispunjava preduvjete dobroga književnoga teksta koji ne treba posebno prerađivati ili preoblikovati radi metodičkih razloga jer uspješno ostvaruje sve preduvjete - pedagoške, književne, umjetničke, leksičke, stilističke, jezikoslovne. Stoga se pojedini ulomci mogu iskoristiti kao lingvodidaktički predlošci na temelju kojih je realizirana poticajna, zanimljiva i svrhovita nastava hrvatskoga jezika. 
Prednost odabira književnih tekstova njihova je umjetnička vrijednost te mogućnost međupredmetne korelacije, zatim njihova sadržajna poticajnost, birani jezik i zanimljiv kontekst, ali i odgojni čimbenici. Roman Hrvoja Kovačevića Tajna mačje šape upravo je takav tekst. Kako je riječ o izrazito slojevitome djelu, može se analizirati tijekom nastave književnosti, ali i vrlo svrhovito poslužiti kao paradigmatski primjer lingvodidaktičkoga predloška u procesu učenja i poučavanja materinskoga jezika. U Nastavnome planu i programu za osnovnu školu (2006.), sukladno načelu korelacije i integracije unutar jezično-komunikacijskoga i jezično-umjetničkoga područja, ali i drugih područja izvan predmeta Hrvatski jezik, istaknuta je potreba za povezivanjem nastavnih sadržaja kao poticaj i polazište za olakšano učenje i usvajanje jezičnih sadržaja.

Navedeno je načelo u potpunosti opravdano, ali takav pristup tematici otvara nekoliko problemskih pitanja. Ako je u naputcima NPiP-a istaknuta potreba i svrhovitost povezivanja književnih i jezičnih sadržaja, ako je didaktičko načelo korelacije i integracije nastavnih sadržaja izrazito važno, ako je književni tekst izrazito primjeren motivacijski postupak u nastavi jezika, ako je izbor zanimljivoga i učeniku bliskoga teksta kao lingvometodičkog predloška poticaj za stvaralačku i učinkovitu nastavu materinskoga jezika - zašto se u biblioteci Metodički obrađena lektira uopće ne predlaže jezikoslovna analiza, odnosno ne potiče mogućnost da se polazni umjetnički tekst iskoristi i kao lingvodidaktički predložak na osnovi kojega bi se usvajali raznoliki jezični sadržaji?

Zašto nastavnici, nakon književnoteorijske analize umjetničkoga teksta, isti tekst ili ulomak teksta vrlo rijetko koriste kao predložak u nastavi jezika? Nastavnici se najčešće opravdavaju činjenicom da za takav način rada na tekstu ne postoje gotove metodičke pripreme, da je riječ o zahtjevnijoj nastavi koja traži veći individualni angažman, da se u knjigama metodički obrađene lektire poticaji odnose samo na književnu analizu (razmišljanje o pročitanome djelu, izražavanje doživljaja, tema djela, tijek radnje, analiza likova...). Od jezikoslovnih se sadržaja tematizira samo leksička razina, a i to vrlo rubno (objašnjene su nepoznate riječi). Osim toga, nastavnici često nisu sigurni hoće li znati izdvojiti ulomak teksta koji će poslužiti kao ishodišni predložak te, sukladno tome, hoće li prezentacija jezičnih sadržaja biti primjerena.

\section{Primjeri jezikoslovne analize na ulomcima tekstova iz romana Tajna mačje šape}

Prema jezikoslovnim kriterijima, na ulomcima umjetničkih tekstova mogu se ostvariti raznoliki usporedni, motivacijski ili asocijativni poticaji, ali uvijek primjereni funkcionalnoj, učinkovitoj i zanimljivoj nastavi hrvatskoga jezika. Prozni tekst - uzorak upoznaje se najprije usmjerenim izražajnim čitanjem te vođenom književnom analizom, a tek zatim slijedi osvrt na razini jezičnoga izražavanja, analiza 
rečeničnoga ustroja, analiza leksičkih jedinica na gramatičko-pravopisnoj i semantičkoj razini, usporedba piščeva i učenikova rječnika, objašnjenje nepoznatih riječi, moguće stvaralačke preoblike teksta. Naime, na predlošku svakoga ishodišnoga teksta može nastati metatekst, a njegove će značajke osvisiti o funkciji polaznoga teksta i obrazovnim ishodima nastave (Rosandić, 2002.).

Tijekom lingvodidaktičke i lingvostilističke analize triju ulomaka iz romana Tajna mačje šape (str. 28, 63 i 66) predlaže se primjena suvremenoga komunikacijskofunkcionalnoga pristupa učenju i poučavanju hrvatskog jezika, temeljenoga na načelima humanističke edukacije, jer u obrazovni proces, osim jezičnih, uključuje i izvanjezične elemente kao što su emocije, osobine ličnosti, društveni odnosi, okruženje (Pavličević-Franić, 2005.). U potrazi za brojnim i raznoliko oblikovanim postupcima i izvorima informacija, taj pristup implicira osviještene i promišljene napore brojnih stručnjaka u pronalaženju što svrhovitijih i učenicima zanimljivijih načina učenja i usvajanja gramatičkih sadržaja standardnog jezika. Riječ je o didaktičkome modelu koji je komunikacijski jer potiče razvoj komunikacijskih sposobnosti svih vrsta, a ponajprije jezičnih; funkcionalan jer apstraktan sadržaj kakav je gramatika tretira u funkciji svakodnevnoga sporazumijevanja; integracijski jer uključuje korelaciju i integraciju sadržaja unutar područja hrvatskoga jezika (ponajprije jezičnoga izražavanja i književnosti), ali i izvanjezičnoga područja. Taj je pristup i stvaralački jer potiče kreativno mišljenje te logičko zaključivanje s mogućnošću višekratnih izbora, a ne samo memoriranje i što točnije reproduciranje gramatičko-pravopisnih pravila (Erasmus+ projekt, Smjernice za poučavanje, 2016.). Dakle, komunikacijsko-funkcionalni pristup daje prednost uporabnoj jezičnoj komunikaciji. Pritom se didaktička igra smatra važnim motivacijskim čimbenikom i temeljnom aktivnošću (Čudina-Obradović, 1995.), a indukcija polazišnom metodom rada. Igra pridonosi otklanjanju monotonije koja je često uzrokom pada koncentracije i motivacije u obrazovnom procesu. Ona pridonosi intenziviranju raznovrsnih aktivnosti učenika te potiče odgojnu komunikaciju. Dijete ima dojam da se igra, a obrazovni se ishod ostvaruje nesvjesno, kao sekundarni element (Pavličević-Franić, 2002.). Uz to, pluralizam načela i postupaka omogućuje ostvaraj zanimljivoga i raznolikoga, a ipak svrhovitoga procesa učenja hrvatskoga jezika.

Nastavom jezika naziva se nastavno područje u kojem se proučava i poučava fonološko, morfološko, sintaktičko, leksikološko, dijalektološko, stilističko gradivo te gradivo iz povijesti jezika i drugih jezikoslovnih disciplina (NPiP, 2006.). Mogućnosti su, doista, brojne i raznolike te učenicima osnovne škole uglavnom primjerenije od tradicionalne jezične poduke. Uz pomoć i na temelju književnoga teksta kao lingvodidaktičkoga predloška mogu se obraditi gotovo svi jezikoslovni sadržaji propisani NPiP-om za mlađe razrede osnovne škole. U drugome razredu, to je niz nastavnih jedinica u području jezičnoga izražavanja (pripovijedanje prema poticaju, 
prepričavanje s proširivanjem ili sažimanjem sadržaja, pričanje priče, stvaran opis lika...) te nastavne jedinice iz područja gramatike i pravopisa (opće i vlastite imenice, rečenični ustroj, red riječi u rečenici, pisanje velikoga početnoga slova u imenima ulica, mjesta, blagdana...). U trećemu razredu to su nastavne jedinice: razgovorni jezik (dijaloška komunikacija), rasprava, obavijest, čitanje po ulogama te jednina i množina imenica, umanjenice i uvećanice, glagoli, opisni i posvojni pridjevi. U četvrtome razredu ishodišni književnoumjetnički tekst može poslužiti kao poticaj za izražajno čitanje, stvaralačko pričanje i pisanje, usporedbu književnoga jezika i zavičajnoga govora te kao podloga za usvajanje jezikoslovnih sadržaja (rod imenica, izricanje prošlosti, sadašnjosti, budućnosti, upravni i neupravni govor). Naprimjer:

- VRSTE RIJEČI - usvajanje posvojnih i opisnih pridjeva

Polazi se od naslova romana "mačja šapa“, slijedi usporedba sintagme mačja šapa i mačkina šapa te utvrđivanje značenjske razlike. Zatim se aktivnost proširuje na slične primjere (mačji kašalj/mačkin kašalj; žablji krakovi/žabini krakovi; pasji, pseći život/pasov, pesov, pasićev život), te na samostalno izvođenje pridjeva prema imenima likova iz romana (Marica - Maričin, učiteljica - učiteljičin, Zigi-Zigijev, Ante - Antin...). U tijek sata uključuje se i tjelesna aktivnost u obliku didaktičke igre: kada učiteljica/učitelj izgovori opisni pridjev, učenici trebaju podići ruke uvis, a kada izgovori posvojni pridjev, moraju prekrižiti ruke na grudima.

- TVORBA RIJEČI - tvorba složenih imenica i pridjeva

Inicijalni uzorak riječi jest ime jednoga od likova iz romana - Mačkoglav. Prema tome tvorbenome uzorku učenici stvaraju složena vlastita imena opće imenice te složene pridjeve. Npr. Lavoslav, Miroslav, Tihomir, Predrag..., nogomet, padobran, zrakoplov, vodovod, slikopriče..., gologlav, tordoglav, crnokos, ljevoruk ... Također se tijekom aktivnosti može provesti kraća igra u parovima: jedan učenik zada riječ (primjerice: voda), a drugi doda drugu riječ (primjerice padati) te izgovara novonastalu riječ (vodopad).

- MORFOLOGIJA - deklinacija, komparacija, konjugacija

Iz ulomka teksta (npr. sa str. 66), nastavnik odabere nekoliko riječi. Od jedne riječi, mijenjajući joj oblik, učenici trebaju načiniti što više drugih riječi. Npr. zadane su riječi smijeh, čitati, star, a moguće nove riječi su: osmijeh, smiješan, smijati se, smjehuljica, smješko...; pročitati, iščitati, čitatelj, čitateljica, čitanka, čitanje...; starac, starica, starost, starenje, Starigrad. Zatim se od imenica mogu izricati padežni oblici, jednina i množina, rod, umanjenice i uvećanice. Glagole učenici mijenjaju izričući konjugacijske oblike u sadašnjemu, prošlome ili budućemu vremenu, a pridjeve stupnjuju. 
- SINTAKSA - preoblike rečeničnoga ustrojstva

Iz ulomka teksta sa str. 63, nastavnik izdvaja rečenice na osnovi kojih postavlja pitanja. Npr. nastavnik pita: Kada bi policiji bilo lakše? Od učenika se očekuje da u ulomku pronađu rečenicu koja daje odgovor na postavljeno pitanje (, Policiji bi bilo lakše da ih je vidjela samo jedna osoba."). Nakon toga rečenice treba preoblikovati jesne u niječne (i obrnuto), izjavne $u$ upitne ili usklične, upitne jesne u upitne niječne itd. (Policiji ne bi bilo lakšse da ih je vidjela samo jedna osoba., Policiji bi bilo lakše da ih nije vidjela samo jedna osoba; Bi li policiji bilo lakše...?, Ne bi li policiji bilo lakše...?).

- LEKSIKOLOGIJA - usvajanje višeznačnosti riječi, bogaćenje rječnika, zavičajni/ standardnojezični idiomi

Iz ulomka teksta sa str. 63. nastavnik izdvoji riječi koje mogu biti višeznačne, npr. slegnuti, zviznuti, strašno... Vođenim razgovorom dolazi se do mogućih značenja navedenih riječi. Zatim učenici trebaju smisliti i izreći rečenice u kojima će upotrijebiti sva različita značenja riječi. Osim toga, nastavnik može iz odlomka izdvojiti riječi pogodne za stvaranje sinonimskih/antonimskih parova (npr. zgodan, pristojan, različit, reći, sâg, mlad...) ili pak uočavati razliku između standardnojezičnih i zavičajnih leksema (fini dečki, malo je falilo, zviznuli su nam perzijaner, strašno pristojni, di ste? ...)

- PRAVOPIS - pisanje velikoga početnoga slova u nazivima ulica, trgova, naseljenih mjesta, bilježenje fonema č/ć

Na osnovi ulomka sa str. 66-67 provodi se vođeni kolektivni razgovor. Nastavnik postavlja pitanja: Odakle je došao novi dječak? U kojoj ulici živi Maričina baka? U kojem gradu stanuju Domagojevi djed i baka? Kamo je Domagoj otišao tražiti Maricu? U svim rečenicama-odgovorima nalazi se pravopisni sadržaj koji se usvaja - pisanje velikoga početnoga slova (Došao je iz Bosne, Baka živi u Kamaufovoj ulici u Zagrebu, Oni stanuju u Požegi, a on u Zagrebu...). Nakon navedenih jezičnih djelatnosti nastavnik može proširiti aktivnost na stvarne komunikacijske situacije iz svakodnevnoga života učenika. Npr.: Uputite nekoga kako može doći iz vaše ulice na središnji gradski trg. Zapišite svoju uputu u bilježnicu. Podcrtajte sve glagolske oblike u tekstu. Koji ste glagolski oblik najčešće upotrebljavali?

Osim toga, ulomak je zasićen riječima koje sadrže foneme č ili ć, pa se također može vježbati izgovor i pisanje glasova (npr. dječak, čovjek, Maričin, slastičarnica, ulični svirači, zaključak, kuća, moguće, osjećaj, reći, treća, već...). Za isti se sadržaj artikulacijskih vježbi može iskoristiti i ulomak sa str. 28.

- JEZIČNO IZRAŽAVANJE - stilsko-kompozicijske vježbe

Stilsko-kompozicijske vježbe vrsta su jezičnih vježbi provođenjem kojih se u sustavu jezičnoga izražavanja potiče usmena i pisana komunikacija. Potiču stvaranje 
ortoepskih i ortografskih navika te pomažu učenicima pri ustroju i stilskome oblikovanju usmenih i pismenih iskaza. Na odabranim se ulomcima iz romana Tajna mačje šape mogu realizirati nastavne jedinice: stvaran opis lika, pripovijedanje prema poticaju, rasprava, sažimanje i proširivanje priče, čitanje po ulogama, usmena dramatizacija, razgovorne forme izražavanja (dijalog) i sl.

\section{Zaključak}

Poučavanje i učenje jezika, osobito materinskoga, povezano je ne samo s učenikovim jezičnim nego i psihokognitivnim razvojem te je sukladno tome temeljno sredstvo stjecanja različitih područja znanja i razvoja spoznajnih sposobnosti (Jelaska, 2007.). Pritom ovladavanje materinskim jezikom ima dvojaku funkciju: jezik čini sadržaj nastavnoga predmeta Hrvatski jezik, ali je ujedno i komunikacijska osnovica sporazumijevanja u svim školskim i izvanškolskim djelatnostima. Stoga se od sudionika obrazovnoga procesa očekuje da na kraju izobrazbenoga puta razina usvojenosti hrvatskoga standardnoga jezika bude što viša. Međutim, unatoč svijesti o važnosti i potrebi učenja materinskoga jezika, situacija u školskoj praksi potvrđuje činjenicu da učenicima završnih razreda osnovne škole izražavanje na hrvatskome standardnome jeziku predstavlja problem (Miljević-Riđički i sur., 2003.; PavličevićFranić i Aladrović Slovaček, 2011.).

Jezikoslovnome se znanju u osnovnoj školi, u odnosu na ostale nastavne predmete, posvećuje dostatna pozornost, barem kad je riječ o broju sati. Za nastavni predmet Hrvatski jezik predviđena je najopsežnija satnica, $4-5$ sati tjedno (NiPP, 2006.). No, obrazovni ishodi nisu u skladu s očekivanjima. Nažalost, kad je riječ o pismenosti i jezičnim kompetencijama, naši učenici na PISA-inim testiranjima (engl. Programme for International Student Assessment) ostvaruju loše rezultate, a to potvrđuju i znanstvena istraživanja provedena u Hrvatskoj (Jelaska, 2007.; Kuvač i Palmović, 2007.; Pavličević-Franić, 2011.). Razloga je više, a valja istaknuti najvažniji. Načini prezentacije jezičnih sadržaja, očito, nisu primjereni dobi i interesima učenika, osobito u mlađim razredima osnovne škole. Iako se u nastavnome programu ističe važnost komunikacijskoga, funkcionalnoga i stvaralačkoga učenja i poučavanja, u praksi se i nadalje veća pozornost posvećuje teorijskome poznavanju jezikoslovnih definicija i pravila (lingvistička kompetencija).

Suvremena bi škola trebala ponuditi učinkovite te učenicima primjerene i zanimljive pristupe, metode i postupke koji bi učenicima omogućili da na kraju izobrazbenoga procesa uspješno ovaladaju hrvatskim jezikom te postanu govornici visoke razine jezičnoga znanja i pouzdanja (Pavličević-Franić, 2011.). Kako su učenicima mlađe osnovnoškolske dobi jezikoslovni sadržaji apstraktni i teže usvojivi, gramatičko-pravopisne nastavne jedinice trebalo bi poučavati u skladu sa smjernicama 
komunikacijsko-funkcionalnoga pristupa. To znači da učenicima treba ponuditi zanimljive, nestereotipne, stvaralačke, a ipak svrhovite sate hrvatskoga jezika. Jedan od uspješnih načina svakako je integracija sadržaja i korelacija između nastave jezika i književnosti.

U radu je, upravo stoga, tematizirana uporaba književnoumjetničkih tekstova kao lingvodidaktičkih predložaka. Provedeno istraživanje i primjeri iz prakse potvrđuju da se u nastavi hrvatskoga jezika i jezičnoga izražavanja treba polaziti od teksta i tekstu se vraćati. Dobro odabran književni tekst, koji je pritom zasićen jezičnim činjenicama, poslužit će učitelju kao poticaj i polazište za ovladavanje određenim gramatičko-pravopisnim sadržajima ili, pak, za stvaranje vlastitih funkcionalnih tekstova. Današnji učenici žele biti aktivni subjekti u nastavi, a to mogu ostvariti ako im se omogući aktivno učenje otkrivanjem, istraživanjem, igrom i radom.

\section{Literatura}

Barić, Eugenija i sur. (1996), Hrvatska gramatika. Zagreb: Školska knjiga.

Čudina-Obradović, Mira (1995), Igrom do čitanja. Zagreb: Školska knjiga.

Erasmus+ projekt (2014.-2016), Creative thinking in Literacy and language Skills. Smjernice za poučavanje. Zagreb: Učiteljski fakultet. http://wwww.ufzg.unizg.hr/.

Howe, Michael J. A. (2002), Psihologija učenja. Jastrebarsko: Naklada "Slap“.

Jelaska, Zrinka (2007), Teorijski okvir jezikoslovnomu znanju u novom nastavnom programu hrvatskoga jezika za osnovnu školu. U: M. Češi i M. Barbaroša-Šikić (ur.), Komunikacija u nastavi hrvatskoga jezika: suvremeni pristupi poučavanju u osnovnim i srednjim školama. Zagreb: Naklada "Slap“ i Agencija za odgoj i obrazovanje.

Kovačević, Hrvoje (2013), Tajna mačje šape. Moja Knjiga - metodički obrađena lektira. Zagreb: Školska knjiga.

Kuvač, Jelena i Palmović, Marijan (2007), Metodologija istraživanja dječjega jezika. Jastrebarsko: Naklada "Slap“.

Miljević-Riđički, Renata i sur. (2000), Učitelji za učitelje: primjeri provedbe načela aktivnel efikasne škole. Zagreb: IEP.

Nacionalni okvirni kurikulum - NOK (2010), Zagreb: MZOS, Vijeće za NOK.

Nastavni plan i program za osnovnu školu - NiPP, Hrvatski jezik (2006), Zagreb: Ministarstvo znanosti, obrazovanja i sporta.

Pavličević-Franić, Dunja (2002), Razvoj funkcionalne komunikacije u nastavi hrvatskoga jezika. U: M. Matijević (ur.), Zbornik Učiteljske akademije u Zagrebu. Zagreb: Učiteljska akademija u Zagrebu, 4 (1), str. 169-177.

Pavličević-Franić, Dunja (2005), Komunikacijom do gramatike. Zagreb: Alfa. 
Pavličević-Franić, D. (2011), Jezikopisnice. Zagreb: Alfa.

Pavličević-Franić, Dunja i Aladrović Slovaček, Katarina (2011), Utjecaj načina poučavanja na motivaciju i stav učenika prema hrvatskome jeziku kao nastavnome predmetu. Napredak. 152 (2), str. 171-188.

Rječnik hrvatskoga jezika (2000), Zagreb: leksikografski zavod Miroslav Krleža i Školska knjiga.

Rosandić, Dragutin (2002), Od slova do teksta i metateksta. Zagreb: Profil.

Samardžija, Marko i Selak, Ante (2001), Leksikon hrvatskoga jezika i književnosti. Zagreb: Pergamena.

Saussure, Ferdinand (2000), Tečaj opće lingvistike. Zagreb: Artresor naklada, Institut za hrvatski jezik i jezikoslovlje.

Silić, Josip i Pranjković, Ivo (2005), Gramatika hrvatskoga jezika. Zagreb: Školska knjiga. Solar, Milivoj (2005), Teorija knjižeonosti. Zagreb: Školska knjiga.

Težak, Stjepko (1998), Teorija i praksa nastave hrvatskoga jezika 1. i 2. Zagreb: Školska knjiga.

\section{Hrvoje Kovačević's Novel The Mystery of a Cat's Paw as a Paradigmatic Example of Lingo-Didactic Template in Croatian Language Teaching}

\section{Summary}

In professional literature, lingo-didactic template is defined as an original functional text, which is analysed in order to achieve cognitive goals and language acquisition. The novel The Mystery of a Cat's Paw by Hrvoje Kovačević is an obligatory reading text in the fourth grade of primary school, and therefore provided for analysis in the context of teaching literature. Since this is a multi-layered text, it can also very purposefully serve as a paradigmatic example of a lingo-didactic template in the process of teaching and learning the mother tongue.

From the literary aspect, Kovačevićs novel is an interesting and very dynamic artistic text with a branched plot and a clear structure, as well as with socially sensitive background and a touch of symbolism that directs young readers to true values. From the lingo-didactic aspect, which is the topic of this paper, the novel is saturated with short, understandable and logical sentences, appropriate syntax and style, and with substantially complete and sufficiently informative dialogues appropriate for everyday language expression. Moreover, last but not least, the text offers extensive vocabulary marked by occasional traits of dialectal or age-related communication.

Therefore, in this article, in accordance with the principle of correlation and integration of educational content within the linguistic-communicative and artistic context, some fragments 
of Kovačević 's novel may be treated as a starting point for stimulating, creative, interesting and purposeful teaching of Croatian language.

Keywords: lingo-didactic template; teaching Croatian in primary school; children's literature; novels by Hrvoje Kovačević.

Red. prof. dr. sc. Dunja Pavličević-Franić

Učiteljski fakultet Sveučilišta u Zagrebu

Savska cesta 77, 10000 Zagreb

dunja.pavlicevic-franic@ufzg.hr 